\title{
Oral Gavage Route of Administration
}

National Cancer Institute

\section{Source}

National Cancer Institute. Oral Gavage Route of Administration. NCI Thesaurus. Code C78374.

Administration through the mouth and into the stomach, usually by means of a tube. 